\title{
FRANZ HUBERTI (1715-1789), STEPLINGŮV PŘÍTEL A KORESPONDENT
}

\author{
HANS-JOACHIM VOLLRATH
}

\section{FRANZ HUBERTI (1715-1789), STEPLING'S FRIEND AND CORRESPONDENT}

This contribution presents a brief overview of the life and work of an important representative of eighteenth-century German Jesuit science. Franz Huberti started his academic career in Fulda, but soon moved to Würzburg, where he stayed until the end of his life. Huberti was mainly a teacher and author of numerous textbooks of mathematics and physics. Towards the end of his life, he was also active in the codification of units of measurement. His most important contribution to science, however, was the construction of an astronomic observatory at the Würzburg university. He was a dedicated friend of Josef Stepling of Prague: he corresponded with him for many years and visited him twice. He was helping to acquire instruments for the Prague observatory, which was at the time being furnished. Most of these instruments were imported from England, but the mural quadrant was produced for Stepling by his own mechanist.

Keywords: German Jesuit science - textbooks of mathematics and physics - construction of an astronomic observatory in Würzburg

DOI: $10.14712 / 23365730.2018 .50$

V seznamu ,největšich evropských matematikư“, s nimiž si Stepling dopisoval, jmenuje František Martin Pelcl i Franze Hubertiho. Stanislav Vydra jej označuje za ,známého profesora matematiky ve Fuldě a později ve Würzburgu“. Rovněž würzburská univerzita jej řadí mezi své nejvýznamnější matematiky. Město Würzburg, kde nejdéle působil, uctilo astronoma Hubertiho tak, že po něm pojmenovalo ulici a na věž místního kostela zvaného Neubaukirche dalo osadit pamětní desku (jejím autorem je Otto Volck), která připomíná matematika a astronoma, jenž tu zřídil první würzburskou hvězdárnu. $Z$ dnešního hlediska je Huberti navíc oceňován pro řadu svých matematických spisů, pro svá astronomická pozorování i pro pravidelná pozorování meteorologická, stejně jako i pro práce na uspořádání a sjednocování měr ve würzburském regionu. Přitom všem se Huberti snažil podílet i na mezinárodních výzkumných projektech. Pro protestantského matematika Johanna Matthäuse Hassencampa z Marburgu byl jezuita Franz Huberti ,důkladný a přesný matematik, byla to přitom vtipná hlava a př́jemný společník“. 


\section{Životní dráha}

Johann Franz Huberti se narodil 20. května 1715 v Geisenheimu na Rýně, poblíž Mohuče. Byl tedy o rok starší než Stepling. Studia filozofie zahájil v roce 1731 v Mohuči a po třech letech, v roce 1734, je úspěšně ukončil jako magistr filozofie. Tamtéž vstoupil 13. července 1734 do jezuitského řádu. V následujících letech působil jako učitel, v jezuitské koleji ve Fuldě vyučoval např́klad gramatiku a rétoriku. V letech 1742-1746 studoval v Mohuči teologii. Poté působil v jezuitských kolejích v dnešním Baden-Badenu a v Ettlingen, kde složil 15. srpna 1748 poslední řádový slib a stal se tak konečně a definitivně členem řádu. To vše byl v Societas Jesu typický postup, kterým prošel jen s nepatrným časovým posunem i Stepling. Poté se však kariéry obou mužů začaly ubírat poněkud jiným směrem. Steplingovi osud umožnil, že se mohl daleko víc věnovat, jak bychom dnes řekli, vědeckému výzkumu, problémům, které jej zaujaly. Psaní učebnic přenechával svým řádovým kolegům a na filozofické fakultě rychle dosáhl vysokých funkcí a uznávaného postavení. Naopak Huberti byl daleko více svázán s vlastním pedagogickým posláním fakulty.

\section{Profesorem v Heiligenstadtu a ve Fuldě}

Huberti započal svou odbornou pedagogickou činnost v roce 1749 v jezuitské koleji v Heiligenstadtu, což bylo lázeňské městečko ležící v Durynsku, jihovýchodně od Göttingen, a to jako profesor logiky a poté experimentální fyziky. Na podzim roku 1751 byl přeložen do Fuldy jako řádný profesor matematiky. Tady také vycházejí jeho první matematické učebnice: Compendium arithmeticae vulgaris (1751), Epitome geometriae (1751) i Prima mechanicae elementa (1752). Zvolená označení jako Compendium (Shrnutí), Epitome (Nástin) a Elementa (Základy) tyto spisy omezují co do formy i obsahu; jedná se jen o elementární učebnice. Přesto však vykazují určitou zvláštnost: jejich texty byly vydávány vesměs u přiležitosti veřejných závěrečných magisterských obhajob. Úlohou studenta bylo obhájit hlavní teze profesora, který spisek napsal, čímž měl prokázat své nabyté vědomosti. Svou učenost tím samozřejmě prokazoval zároveň i profesor. Tehdy se praktikovalo zcela všeobecně - i když to bylo již dlouho předmětem různých kritik -, že se přednášky studentům diktovaly. $Z$ tohoto hlediska je pozoruhodné, že následující tituly řady Hubertiho učebnic začínají jinak: Institutionum mathematicorum opusculum („Malé dílko k výuce matematiky“). Jedná se o několik knih, které vycházely ve Frankfurtu i Mohuči: Arithmetica (1753), Geometria (1754), Mechanica (1756) a dvousvazková Hydrodynamica (1758). Kniha z roku 1753 je bohužel jediným Hubertiho spisem, jejž má dnes pražská Národní knihovna ve svých fondech. K jeho matematickým dílům patři konečně i Rudimenta algebrae (Základy algebry), které vyšly v roce 1762 ve Würzburgu.

Vedle svých učitelských povinností podnikl Huberti v této době také několik - jak se tehdy ř́kávalo - učených cest, a to do Dillingen, Ingolstadtu, do Prahy a do Vídně. Všechno to byla univerzitní města s řádovými kolejemi. V Praze se setkal s astronomem a všestranným jezuitským vědcem Josefem Steplingem (1716-1778), s nímž jej pak až do konce života spojovala přátelská korespondence.

Jejich prvý dnes známý dopis nese datum 20. března 1752 a napsal jej z Fuldy Huber-

ti. Začíná poděkováním, z něhož vyplývá, že Huberti zaslal Steplingovi už předtím 
k posouzení rukopis nějaké své nejmenované, dosud nevydané knihy; nyní jej dostal patrně s nějakými Steplingovými poznámkami a určitě s jeho schválením - zpět a děkuje mu za vykonanou práci. $Z$ chronologie se zdá, že to patrně byla Hubertiho výše zmíněná Aritmetika, která pak vyšla v příštím roce 1753 . Není také asi náhoda, že právě tento výtisk, jak jsme se již zmínili výše, je dodnes uložen ve fondu pražské Národní knihovny. Př́šstí generaci badatelů pak zbývá, aby se dopátrali, kdy a za jakých okolností jejich vzájemný styk skutečně začíná a kdo jej zprostředkoval. Za zmínku stojí, že Steplingova odpověd' je datována dnem 26. břrezna 1752. Svědčí to jednak o poměrně značné rychlosti tehdejší pošty (dopis putoval jen šest dnů), ale zároveň i o Steplingově zřejmém zájmu: odpověděl bez jakéhokoli prodlení. Stepling ve svém listu odmítl větší díky, jež si za tuto práci zaslouží, vykonal ji prý rád (,non sine voluptate“) a mimo jiné i proto, že jej Huberti požádal o posouzení svého rukopisu s mimořádnou skromností (,singulare modestia“). Stepling reagoval ve své odpovědi i na problém, který Huberti nadhodil ve svém dopise, jenž se týkal parabolických zrcadel. Detailně mu, nikoli bez hrdosti, popsal jejich dvojici, kterou má $\mathrm{k}$ dispozici klementinské matematické muzeum.

Hubertiho korespondence se Steplingem pak trvala dlouhá léta, poslední list byl napsán ve Würzburgu dne 20. dubna 1771. Tato korespondence má pro nás nesmírný význam, protože obsahuje značné množství informací o odborné činnosti obou vědců. Dodnes se z ní zachovalo celkem dvacet dva dopisů: devatenáct jich napsal Huberti, Stepling jen zbylé tři. To je velmi nevyvážené rozložení, nebot' z obsahu zachovaných listů je zřejmé, že Steplingových dopisů muselo být daleko víc. Pátrání, které jsme v této věci podnikli ve würzburgském univerzitním archivu, nevedlo bohužel k pozitivním výsledkům; druhá světová válka vykonala i zde své zhoubné dílo.

\section{Profesorem ve Würzburgu}

Prvá dvě Hubertiho Opuscula byla vydána v době, kdy ještě působil ve Fuldě. Následujících dvou svazků se dočkal až ve Würzburgu. Tam byl 9. listopadu 1754 zapsán pod č. 1811 do univerzitní matriky jako „Professor Mathes[eos] Publ[icus] et ord[inarius]“, tedy jako řádný profesor matematiky. Jako takový měl za povinnost vyučovat matematickým vědám matematika v tehdejším užším pojetí zahrnovala aritmetiku, algebru a geometrii, vyučovat se měly i jejich praktické aplikace. Pro experimentální fyziku existovala ve Würzburgu od roku 1749 samostatná profesura. To, co Huberti skutečně učil, bylo dáno především dlouholetou tradicí, což lze ostatně vyčíst z jeho Institutiones.

\section{Matematické práce}

Jednotlivé svazky Hubertiho matematických knih odrážejí historický vývoj v daných disciplínách a naznačují, jak se postupně vyvíjely.

V Aritmetice se Huberti opírá o známé, opakovaně vydávané dílo André Tacqueta (1612-1660) Arithmeticae theoria et praxi (1656). Pozornosti zasluhuje způsob, jímž pracuje s desetinnými zlomky. Ty byly sice už dlouho známy, v praxi se ale začaly uplatňovat teprve s prosazením decimálního systému. Huberti je proto studentům soustavně vštěpoval. 
Širokého uplatnění našly zlomky i v jeho pracích o mírách a váhách. S pojmem záporného čísla však nikdy nepracoval.

Geometrii Huberti zahajuje obsáhlým historickým výkladem. Opírá se přitom samozřejmě o Euklida (300 př. Kr.) a jeho Elementa. Na konci knihy přidává přehled, který ukazuje, kde lze probíranou látku nalézt $\mathrm{v}$ Euklidovi. Hubertiho postup je přitom nápadně pragmatický. Kde to jde, argumentuje proporcemi, z Element pak vybírá zejména konstrukční úlohy, často tak, aby je bylo možné použit pro práci s nástroji. Obdobným způsobem zavádí i trigonometrii, aby se mohla použít pro řešení praktických úloh.

V obsahu i stylu knihy Rudimenta algebrae navazuje Huberti na svou Aritmetiku. V matematických pracích ulpíval jen na elementární matematice (to je rozdíl proti Steplingovi, který do Čech šíril tzv. vyšší matematiku), snažil se ji však „Zvědečtit“. Na tomto základě probíhá i výklad ve všech Hubertiho matematických knihách. Byly vytvořeny podle vzoru Euklidových Základi̊ a podle tehdejších matematických zvyklostí. To znamená podle geometrického způsobu, ,more geometrico“. Pojmy jsou zavedeny v definicích (Erklärungen), jejich vlastnosti jsou formulovány ve větách (propozicích - Aussagen) a zdůvodněny $\mathrm{v}$ demonstracích, důkazech (Beweisen), které se opírají o axiomy dané předem. Korollaria (Folgerungen) vyplývají bezprostředně z proporcí. Problémy neboli úlohy (Aufgaben) jsou řešeny pomocí axiomů, vět a korollarií.

\section{Astronomické práce}

Série Hubertiho matematických učebnic končí knihou Rudimenta algebrae z roku 1762; od následujícího roku se musel omezit pouze na astronomii. Už v roce 1757 byl totiž Huberti pověřen zařizováním nově vybudované hvězdárny. Aby se na tento úkol připravil, podnikl na podzim roku 1757 studijní cestu do Paříže, a to společně s heidelberským profesorem matematiky Christianem Mayerem (1719-1783), který studoval ve Würzburgu. Tento význačný astronom byl údajně českého původu, měl se narodit v Meziříčí - neví se jen, ve kterém. V Paříži se Huberti seznámil s několika skvělými osobnostmi: byli to především Nicolas Louis de Lacaille (1713-1762) a César François Cassini (1714-1784). Při té př́iležitosti došlo ke zvláštní epizodě, o níž Huberti referuje Steplingovi v listě z 22. dubna 1758. De Lacaille se jej dotázal, které že z univerzit jsou v Německu nejproslavenější a kde že nejvíce vzkvétá studium astronomie. „Mezi prvými jsem jmenoval univerzitu pražskou a v ní jako vynikajicího astronoma tebe“",,inter primas Pragensem, et in hac Te astronomum eximium nominavi“"), odpověděl prý Huberti. Slavný francouzský astronom na to reagoval tak, že věnoval Hubertimu svou nejlepší knihu a požádal jej, aby ji předal Steplingovi. Huberti ji svěřil k doručení jakémusi Meyerovi, knihovníkovi z Norimberka, který se patrně chystal do Prahy. Huberti však chtěl hned od Steplinga protislužbu: měl mu po tomto knihovníkovi poslat optický spis od pražského profesora Jana Jünglinga (1705-1775), nejspíše to měl být jeho Tractatus dioptricus de generalis refractionis principiis..., Pragae 1747. Navíc požádal o katalog české provincie, o pražské teze a disertace za poslední čtyři roky a konečně také o různobarevné čočky průměru asi čtyři palce; jsou prý v Praze nesrovnatelně levnější. Je vidět, že Huberti nebyl z nejskromnějších. Vrat’me se však k de Lacailleovi: dnes je těžké odhadnout, jakou knihu mohl Steplingovi poslat. Předpokládáme, že kniha se později mohla se Steplingovou knižní pozůstalostí dostat do 
fondu klementinské knihovny. Ta má dodnes de Lacailleových spisů poměrně hodně: $z$ knih vydaných roku 1757, z nichž de Lacaille své knižní dárky nejspíše poskytoval, to mohly být Lectiones elementares astronomiae, geometriae et physicae..., které vydal tohoto roku vídeňský nakladatel Trattner (týž, který začal tehdy vydávat i Hellovy efemeridy); naznačuje to alespoň Steplingův dopis Hellovi z 30. srpna 1758. De Lacailleův knižní dárek byl Steplingovi doručen a ten za něj poděkoval, což byl počátek Steplingovy korespondence s tímto vynikajícím francouzským astronomem, kterou vlastně zprostředkoval Huberti.

Huberti studoval v Paříži nejen vlastní astronomii, ale i její tehdy nejmodernější přístroje. Na základě takto získaných znalostí mohl Huberti i dobře ř́dit výstavbu würzburské hvězdárny. Některé z astronomických př́strojů pro ni vyrobil univerzitní mechanik Johann Georg Fellwöck (1728-1810). Z Hubertiho listů víme, že právě on stavěl zední kvadrant o třech stopách a pěti palcích i pro Steplinga. V listě z 18. března 1766 Huberti hlásí, že kvadrant je hotov a že byl také poprvé odzkoušen. Př́sstroj by se měl v Klementinu nacházet dodnes. Huberti pro Steplinga zařizoval i nákup dalekohledů. V listě z 5. října 1763 čteme, že mu posílá pětistopý dalekohled, který právě došel od Dollonda, a v následujícím vyslovuje potěšení, že splnil Steplingovo očekávání. Ten pak hned přes Hubertiho objednává další dalekohled, tentokrát sedmistopý achromatický.

Huberti si zařizoval také svou soukromou observatoř, a tak mohl brzy zahájit vlastní pozorování. Je známo, že 6. června 1761 pozoroval přechod Venuše přes sluneční disk - těchto pozorování se po celém světě konalo více než sto dvacet, pokusil se o ně i Stepling. Stejný jev se opakoval po osmi letech, 4. června 1769 , a Huberti se na něj opět pečlivě připravoval. Štěstí mu však nepřálo, nebe bylo toho dne silně zatažené. Pokaždé pozoroval Huberti i zatmění, jedno sluneční a tři měsiční. Jako prvý v Německu objevil v roce 1770 kometu. Hrdě Steplingovi 20. dubna 1771 hlásil: „Pokud jsem se nezmýlil, objevil jsem nedávno jako prvýv Německu novou kometu; od 26. června až do 4. července jsem pozoroval její dráhu."

O Hubertiho astronomické činnosti svědčí také planetárium, které navrhl. Demonstruje názorně oběžné dráhy šesti tehdy známých planet a různé doby jejich oběhu kolem Slunce. Planetárium zhotovil rovněž univerzitní mechanik Fellwöck. Také o tomto modelu podal Huberti do Prahy Steplingovi v dopise z 9. února 1765 podrobnou zprávu. Zdůraznil, že v něm uplatnil zejména své vlastní představy, aby ukázal, že planetárium koncipoval svým způsobem jako astronomické kompendium pro začátečníky. Tehdejší návštěvníci univerzity ho popisovali jako zázračný stroj. Od začátku 20. století se planetárium nachází jako dlouhodobá zápůjčka univerzity ve Würzburgu v Deutsches Museum v Mnichově.

\section{Meteorologická pozorování}

V letech 1765-1770 konal Huberti ve Würzburgu také prvá meteorologická pozorování. Uveřejnil je v tabulkové př́loze ve spisku Observationes meteorologico-thermometricae. Své pozorování odůvodňuje přáním, aby mohl přispět $\mathrm{k}$ meteorologickým pozorováním, která se konají po celém světě. Jedná se $\mathrm{v}$ nich o to, aby bylo možné dělat srovnání spolehlivých pozorování o povaze větru, o podstatě tepla i chladu, o př́ícinách zemětřesení a jiných jevů. Začíná každodenním měřením teplot ve volné prrírodě, $\mathrm{k}$ čemuž používal rtut'ového teploměru s Réaumurovou stupnicí. Později přidal i měření tlaku vzduchu, údaje o směru větru a celkovém počasí. Tlak vzduchu měřil výší rtutového sloupce na barometru, 
výsledky udával v pařížských stopách. Pro ostatní meteorologické jevy jako je déšt', sníh, bouřka nebo kroupy používal vlastní symboly, např́íklad znamení Vodnáře pro déšt' nebo šesticípou hvězdičku pro sníh.

O své meteorologické výsledky se rovněž dělil se Steplingem. V Hubertiho listě ze 7. dubna 1770 čteme, že mu zasílá výsledky svých pozorování za rok 1765 a 1766.

\section{Metrologické práce}

V roce 1771 byl Huberti pověren, aby ve würzburském regionu nově uspořádal míry a váhy. $\mathrm{V}$ okolí bylo např́íklad mnoho obcí s různými mírami na obilí, jejichž vztah $\mathrm{k}$ würzburským byl často neznámý. Šlo tedy o to uvést tyto míry do souladu s městskými mírami a vahami Würzburgu. Problém však spočíval v tom, že ani würzburské míry nebyly stanoveny jednotně. Na počátku bylo proto třeba stanovit základní würzburskou jednotku a určit pro ni vhodný etalon, který by se dal za všech okolností snadno opatřit a použít. V úvahu prricházela krychlová nebo válcová nádoba, jejižz základna i výška by byly pevně stanoveny a vztahovaly by se ke všeobecně uznané délkové míře. Huberti dal proto u známého augsburského mechanika Georga Friedricha Brandera (1713-1783) zhotovit dvě desky dlouhé jednu a půl pařížské stopy, které jsou dodnes uloženy v mohučsko-franckém muzeu ve Würzburgu. V Norimberku pak nechal zhotovit kubickou míru se čtvercovou základnou a stejně velkou míru válcovou pro jednotku zvanou německy „metzen“ (tato míra nemá český překlad), což bylo necelých dvacet dva litru obilí. Obě nádoby se čtyřikrát ztratily: v mohučsko-franckém muzeu je dodnes zachováno jen osm menších nádob od jedné osminy do jedné čtyřiašedesátiny této jednotky, které rovněž pocházejí z Hubertiho pozůstalosti.

V letech 1772-1774 cestoval Huberti po okolí a srovnával místní váhové míry s dubovými nádobami, které si přivezl. Pečlivě shromážděné údaje uveřejnil v roce 1777 pod titulem: Srovnání knižecich wirzburských a mnoha dalši cizich obilních vah s wirzburskou městskou vahou. Franckými vinnými a délkovými mírami se pak Huberti zabýval až do konce života. Výsledkem těchto prací byl rukopis o vinných mírách z roku 1786, který je dodnes uchováván ve würzburské univerzitní knihovně.

Když v roce 1773 došlo ke zrušení jezuitského řádu, zůstal Huberti na svém dosavadním místě univerzitního profesora. Jeho úsilí o poznávání a o široký odborný záběr se dostalo stejně tak jako jeho učebnicím a jeho praktickým výsledkủm všeobecného uznání. Zemřel 2. února 1789 ve Würzburgu.

V textu jsme se několikrát odvolali na Hubertiho korespondenci se Steplingem. Je to vynikající pramen. Kdyby se jej podařilo přeložit a vydat, znamenalo by to pro další bádání o obou učených jezuitech neocenitelný přínos.

\section{Bibliografická poznámka}

BöNICKE Christian, Grundriß einer Geschichte von der Universität zu Würzburg, 2. Teil, Würzburg 1788, s. 161-171

Hassencamp Johann Matthaeus, Briefe eines Reisenden von Pyrmont, Cassel, Marburg, Würzburg und Wilhelmsbad, Bd. 2, Frankfurt und Leipzig 1783 
HupP Ingrid, Arithmetik- und Algebralehrbücher Würzburger Mathematiker des 18. Jahrhunderts, München 1998

Pelzel Franz Martin, Abbildungen Böhmischer und Mährischer Gelehrten und Künstler, Bd. 4, Prag 1782, s. 164-172

ReInDL Maria, Lehre und Forschung in Mathematik und Naturwissenschaften, insbesondere Astronomie, an der Universität Würzburg von der Gründung bis zum Beginn des 20. Jahrhunderts, Neustadt/Aisch 1966

STEPLING Joseph, Litterarum commercium, Wratislaviae 1782

Volk Otto, Mathematik, Astronomie und Physik in der Vergangenheit der Universität Würzburg, in: Peter Baumgart (Hg.), Vierhundert Jahre Universität Würzburg, Neustadt/ Aisch 1982, s. 751-785

Vollrath Hans-Joachim, Würzburger Mathematiker. Aus der Geschichte der Julius-Maximilians-Universität, Würzburg 2010, s. 39-43

WAGNer Gerhard G., - Vollrath Hans-Joachim - van DER Wall Frauke, Maße und Gewichte. Aus den Sammlungen des Mainfränkischen Museums Würzburg, Würzburg 2014

WaGNER Gerhard G., Die Vergleichung der Fruchtmaße von 1777 am Hochstift Würzburg durch Professor Franz Huberti und die Maßplatten von Georg Friedrich Brander, Mainfränkisches Jahrbuch für Geschichte und Kunst 39, 1987, s. 66-77

Wydra Stanislaus, Sätze aus der Mechanik, Prag 1795

Přklad studie Josef Smolka

HANS-JOACHIM VOLLRATH

\section{Franz Huberti (1715-1789), Steplings Freund und Briefpartner}

\section{ZUSAMMENFASSUNG}

Der Beitrag stellt eine Übersicht über Leben und Werk des bedeutenden Vertreters der deutschen jesuitischen Wissenschaft des 18. Jh. dar. Seine Universitätslaufbahn begann Huberti in Fulda, doch wechselte er alsbald nach Würzburg über, wo er bis an sein Lebensende tätig war. Er war in erster Linie Pädagoge, war Verfasser zahlreicher Lehrbücher in Mathematik und Physik und engagierte sich an seinem Lebensende auch bei der Vereinheitlichung von Maßen. Seine bedeutendste Tat war die Errichtung des astronomischen Universitätsobservatoriums in Würzburg. Er war ein ergebener Freund des Pragers Josef Stepling, den er zweimal besuchte und mit dem er jahrelang ausgiebig korrespondierte. Für die in Prag entstehende Sternwarte beschaffte er die notwendigen Geräte, die er überwiegend aus England kommen ließ, den Mauerquadranten für Stepling stellte jedoch sein Mechaniker her.

Deutsche Übersetzung Wolf B. Oerter

Hans-Joachim Vollrath

univerzita Würzburg, emeritni profesor

vollrath@mathematik-wuerzburg.de 